\title{
Macroeconomic Determinants of the Mobilization of Tax Revenues of the Countries of the West African Economic and Monetary Union (WAEMU)
}

\author{
Issa Larba Kobyagda \\ University Ouaga II, Ouagadougou, Burkina Faso \\ Email: kobiss13@yahoo.fr
}

How to cite this paper: Kobyagda, I.L. (2019) Macroeconomic Determinants of the Mobilization of Tax Revenues of the Countries of the West African Economic and Monetary Union (WAEMU). Modern Economy, 10, 237-260.

https://doi.org/10.4236/me.2019.101017

Received: December 27, 2018

Accepted: January 19, 2019

Published: January 22, 2019

Copyright $\odot 2019$ by author(s) and Scientific Research Publishing Inc. This work is licensed under the Creative Commons Attribution International License (CC BY 4.0).

http://creativecommons.org/licenses/by/4.0/

\begin{abstract}
This article aims to analyze the fiscal potential of UEMOA member countries. The question of the fiscal potential of the states is of great importance since the domestic resources represent a high proportion in the financing in Plans and strategies of economic and social development. In this article, we adopt the technique of stochastic border estimation, which is more intuitive-and potentially more relevant for policies-to measure the potential and fiscal effort over the period 1990-2017. The results show that the tax burden is determined by structural factors and that, in most countries, the tax potential is underutilized. Similarly, the fiscal effort shows poor performance in terms of resource mobilization in the majority of countries. These results show that the WAEMU countries can reach or exceed the tax rate of $20 \%$ minimum set by the UEMOA if efforts are made to better tax the informal sector. The main contributions of this article have been to justify empirically the increase of the minimum pressure rate in the UEMOA from $17 \%$ to $20 \%$ and to demonstrate that a better taxation of the agricultural sector would considerably affect the mobilization of tax revenues.
\end{abstract}

\section{Keywords}

Tax Revenues, Tax Pressure, Tax Potential, Tax Effort, Stochastic Border

\section{Introduction}

The financing of economies requires the mobilization of both external and mostly internal resources as recommended by the 2002 Monterrey Consensus on 
Financing for Development. However, fifteen years after this International Conference, the countries of the West African Economic and Monetary Union (WAEMU), like many developing countries, are still struggling to ensure effective mobilization of domestic resources. Indeed, the observation is that the development financing strategies of UEMOA countries were based on a strong mobilization of domestic resources. However, in fact it is public aid for development, multilateral or bilateral debt and foreign direct investment that finance the levers of structural transformation.

In addition, the analysis of budget deficits in the WAEMU countries yields mixed results. According to the 2017 Macroeconomic Convergence Report of the Economic Community of West African States (ECOWAS), the WAEMU budget deficit decreased to $4.1 \%$ of GDP in 2017, compared with 4.3 in 2016, reflecting the increase in revenue and the moderation of recurrent expenditures, offsetting the increase in capital expenditures and other recurrent expenditures. Thus, in WAEMU in 2017, total revenue grew by $7.1 \%$ to $17.8 \%$ of GDP, driven mainly by tax revenues, up $7.7 \%$. The increase in tax revenues is linked to continued efforts in tax administration, computerization of procedures and the fight against fraud. However, the tax pressure rate stood at 15.3\% in 2017 against $15.4 \%$ in 2016. Hence the question of the effectiveness of the mobilization of fiscal or non-fiscal resources arises.

According to Culpeper and Bhushan [1], a strong mobilization of domestic resources in developing countries is a guarantee for the autonomous conduct of the desired policies, since external resources are for the most part conditioned by the technical and financial partners. In addition, several studies [2] [3] show that the large informal economy and the agricultural sector have been neglected as a source of government revenue.

Nearly a decade after the adoption of the decision no. 34/2009/CM/UEMOA of December 17, 2009 adopting the criteria and indicators of the fiscal transition within WAEMU, the analysis of the stylized facts of the principal criteria, including the tax burden ratio and the share of domestic revenue in total revenues, show weak performance in several member countries. Indeed, the tax pressure in the WAEMU is very disparate, and was for example in 2017, 13.3\% in Benin, 16.5\% in Burkina Faso, $15.5 \%$ in Côte d'Ivoire, 10.4\% in Guinea-Bissau, 15.1\% in Mali, $13.1 \%$ in Niger, $15.0 \%$ in Senegal and $20.6 \%$ in Togo.

As a result, countries need to implement economic policies that respond effectively to development challenges if they want to substantially reduce poverty. Under these conditions, the fiscal policy that appears as the set of decisions and characteristic orientations of a tax system should make it possible to finance public expenditure while supporting economic activity. However, it appears from the economic actors (the companies), that taxation is perceived as an unbearable burden; this could discourage investment or even any economic activity as suggested by the Laffer curve. Thus, the concern of optimal collection of taxes must reconcile the financing of public expenditures and the development of the 
private sector, main sources of growth and creators of wealth and jobs in modern economies.

Starting from this principle, knowledge of the tax potential makes it possible to guide choices and implement appropriate policies. According to Brun et al. [4], the fiscal potential of a country is determined by a set of short-term, independent structural factors of economic policy, and notably the measures included in the stabilization programs. With this definition, it is relevant to assess the fiscal potential of the WAEMU countries, which will make it possible to determine the tax effort, defined as the degree of exploitation of the country's fiscal potential, in order to make the best judgment of the effectiveness of the recovery policy to be put in place in each country of the Union. This logic is relevant because some studies show that the current level of taxation of African countries seems higher than the industrialized countries when they had the same per capita income.

The main objective of this article is to analyze the fiscal potential of the WAEMU countries. Specifically, this involves, on the one hand, empirically identify the factors that can influence the tax potential and, on the other hand, evaluate the tax effort.

The first contribution of this research was to show that raising the minimum community tax rate in the WAEMU from $17 \%$ to $20 \%$ in 2015 is justified empirically, but that the countries of the Union taken as a whole can't reach and even exceed this minimum threshold because of the structure of the economies.

The second contribution of this study was to demonstrate that for all the WAEMU countries, agriculture contributes very little and even negatively to tax revenues, with the exception of Togo where its contribution is significant and high. Thus, the knowledge of the potential and the control of the informal sector's base is one of the major challenges of these countries because it is a cost for the State especially in terms of mobilizing tax revenues even if it participates in jobs creation and domestic production.

The rest of the article is organized as follows: after an overview of the economic literature devoted to the evaluation of the fiscal potential, some stylized facts of the revenue mobilization in the WAEMU will be the subject of section 3, the methodology will be presented in Section 4, Section 5 will be devoted to the presentation and discussion of results.

\section{Literature Revue}

Domestic financing of the important basic infrastructure needs of developing countries has been advocated on several occasions for its stability, but also because of the declining trend in public aid for development. It is within this framework that the question of the evaluation of the fiscal potential has found renewed importance in the economic literature, especially in developing countries. In this paper, we define the tax potential as the maximum amount of tax revenue that a country could reasonably generate at a given point in time in rela- 
tion to the structural characteristics of its economy. The tax potential is inherently unobservable-but can be estimated empirically. The tax effort is the extent to which actual tax revenues reach the estimated capacity. It is expressed here in proportion. This effort reflects on the one hand the political choices and the inefficiency in the application of the policies on the other hand. Macroeconomic work in particular covers a variety of fields, including the determinants of fiscal resources and the question of the potential and the fiscal effort of an economy.

\subsection{Theoretical Approaches}

In the theoretical literature, several models [4] [5] [6] have been used to identify the optimal level of government intervention in the economy. In general, these models have similarities about the variable of interest (tax rate) but are different for the outcome variable considered.

The modern theory of optimal taxation and fiscal potential is based on the founding work of Mirrlees [5], who was the first to propose optimal tax modeling. Indeed, one of the functions of taxation in modern economies is that it changes the primary distribution of income through compulsory deductions and transfers. In addition, at the aggregate level, income taxation can lead to changes in individual production or savings and labor choices of economic agents, which can lead to lower tax revenues. Thus, according to Mirrlees [5], it is essential to identify an optimal taxation that maximizes tax revenues for the government while minimizing demotivation to effort by taxpayers. However, the central question is the choice of scales and the form of income taxation that maximizes collective welfare. Mirrlees [5] shows that this choice results from an arbitration between redistribution and economic efficiency, since one seeks to limit the negative effects on the economic activity while pursuing an objective of equity in the considered economy. The main contribution of Mirrlees's [5] theory, which is a questioning of tax progressivity, is that there is a negative relationship between the marginal tax rate that maximizes social welfare and the level of income.

Laffer's model [6] known as the "Laffer Curve" is similar to Mirrlees [5]. Indeed, this model establishes a relationship between the level of taxation (tax rate) and the level of tax revenue mobilized. Laffer [6], unlike the linear relationship identified by Mirrlees [5], finds a quadratic relationship with two contradictory effects on incomes: a positive relationship between the tax rate and the amount of tax revenue and an inverse relationship between tax rate and economic activity. The major result of the Laffer curve is that "too much tax, kill the tax". In other words, there would be an optimal level of taxation beyond which the tax rate acts negatively on the level of tax revenue. This result is similar to that found by Barro [7] in a growth model with productive spending when he says that fiscal policy encourages growth, but beyond this threshold it generates negative externalities that delay growth. Thus, it is necessary to identify the optimal 
rate which would allow an optimal growth, because according to Barro [7], a tax rate too low or very high influences negatively the economy.

Saez [8] shows that while theoretical models of optimal taxation are robust, they are often limited. Thus, Saez [8] will derive the behavioral responses and modelize the optimal tax using the elasticity of labor supply relative to the marginal tax rate or the distribution of allowances. This alternative method has the advantage of allowing simulations to test the effects of taxation and therefore to have a tool to evaluate tax policies and make recommendations on tax reform.

Indeed, a functional tax system requires a minimum threshold of tax pressure in order not to cause distortions in economic activity and to create inequalities because there is a positive link between the taxpayers' ability to pay and the level of production. Indeed, there is a positive relationship between the tax levy and the level of industrialization and therefore the level of development. In addition, the inequity in the distribution of the tax burden is a second limit to the increase of the tax pressure. For example, the highly developed informal sector creates distortions in the system and makes it non-consensual. It is the same for tax evasion, which tend to make the tax burden supported by some taxpayers.

Ultimately, the mobilization of tax revenues depends on structural factors relating to each country. Therefore, for an effective fiscal policy, the authorities must define it according to the chosen economic and social development strategy. It must be supported by a fair, flexible and responsive tax system and must aim for the achievement of clear, coherent and precise objectives. For Bousselhami and Hamzaoui [9] the tax potential of a country is the ability to collect taxes based on laws, the volume of national revenues and the distribution of income. Thus, the difference between the tax potential and the tax revenue or the degree of exploitation of the tax potential is called fiscal effort. It is measured in a general way, according to Brun et al. [4] as the share of public resources determined by economic policy. As a result, a positive fiscal effort tends to signal a fully mobilized resource potential, while a negative fiscal effort indicates a potential for underutilized resources. Therefore, an economic policy that is more favorable to the mobilization of tax revenues should allow the recovery of additional public resources and thus a better exploitation of the resource potential.

\subsection{Empirical Approaches}

In the dynamic of tax revenue mobilization many empirical works have been realized. This work has analyzed and found controversial results on the link between the tax rate and the level of tax revenues on the one hand and the tax pressure on economic growth on the other.

The analysis of this empirical literature reveals rich teachings on the determinants of public revenues and more precisely the fiscal potential. Thus, following Barro [7], several authors have tried to identify the existence of a Laffer curve in order to estimate the optimal tax rate and to evaluate the costs associated with high taxation. 
Branson and Lovell [10] found an optimal rate of $22.5 \%$ of GDP for New Zealand over the period 1946-1995 using a linear programming model. Scully [11] shows that the optimal tax pressure for the United States is between $21.5 \%$ and $22.9 \%$ of GDP for the period 1949-1989 against $19.3 \%$ for the period 1960-1990. The analysis of the empirical results shows that differences could be explained by the method used, the variables used, the period of analysis, and the selected countries.

Brun et al. [4], analyzing the fiscal potential of two groups of countries (countries in transition and developing countries) in panel data, show on the one hand, that the levy rate and the share of mining and petroleum exports are high and on the other hand, agricultural value added tends to decrease the public tax. Using the same method, Chambas et al. [12] shows that Senegal is close to its fiscal potential. However, the impact of the import rate (M2/GDP) and the share of oil exports is positive, while the agricultural added value (agricultural added value/GDP) and the share of mining exports have negative effects on the tax pressure. In addition, the results of Gupta [13] are confirmed by Chambas et al. [12] for agricultural sector variables and the import rate.

This is also valid in the case of Côte d'Ivoire where Keho [14], using the Scully approach [11] finds that over the period 1960-2006, the optimal tax pressure for this country is between $22.1 \%$ and $22.3 \%$ of GDP. In the same vein, Addison and Jorgen [15], analyzing the determinants of tax revenue performance of 39 sub-Saharan African countries including WAEMU countries over the period 1980-2005, find that the tax pressure rate is correlated with the degree of openness of the economy. Authors show that the size of the agricultural sector and public aid for development have a negative impact on the mobilization of tax revenues.

Moreover, in an analysis of Benin's fiscal potential, based on a stochastic border model, Senou [16] shows that in the short term structural factors do not significantly influence the tax pressure. While in the long run an increase in the degree of openness and GDP/head of $1 \%$ respectively leads to an increase of $0.11 \%$ and $0.19 \%$ of the tax pressure. Nevertheless the mobilization of fiscal resources in Benin is below its fiscal potential. Moreover, with a stochastic border efficiency model approach considering the tax lines, Ba et al. [17] show that the margins of progress of tax revenues as a percentage of GDP are estimated at 2.8 points, i.e. a fiscal potential of $22.4 \%$ for the year 2014 .

Saibu [18], analyzing the case of South Africa and Nigeria show that there is a positive relationship between growth and the threshold tax rate. He finds that the optimal tax pressure for South Africa is 15\% of GDP higher than the average tax rate for the period 1964-2012. For Nigeria, the optimal tax pressure is $30 \%$ of GDP below the average tax rate for the period 1970-2012.

Amgain [19], using differently the Scully [11] model and a quadratic model as in the case of the Laffer curve, finds that the optimal tax pressure rate in Asia for an uncooled panel of 32 countries with both models is $18 \%$. However, the results 
of the quadratic model are more consistent and clearly show the existence of a Laffer curve in these countries.

Bousselhami et al. [20] in a sample of countries analyze Morocco's fiscal potential as a panel. Structural factors, namely GDP per capita (proxy for the level of development), degree of openness, industrial added value and degree of monetization have a positive and significant impact. On the other hand, agricultural added value has a significant but negative effect. In addition, they deduce the tax effort of member countries from the sampling. In the case of WAEMU member countries, there is a negative effort for Benin (4.71), Burkina Faso (2.2), Senegal (0.11) and Togo (5.62) therefore spatial fiscal resources are not exploited optimally.

Moreover, the fundamental difference in most of the work is in the methodological approach. This led Brun et al. [4] to argue that the methodological complexity results from the fact that part of the tax revenue may be due to a change in economic policy while the other may be the result of country-specific structural. For other authors such as Bird et al. [21] the focus should be on the role of institutional factors in tax revenue mobilization in developing countries, including corruption and the path to responsibility.

To get around this methodological difficulty, Stotsky and Woldmariam [22] propose a technique for evaluating the tax effort. It consists in isolating economic policy action on tax mobilization. Indeed, the difference between the level of fiscal resources and the structural level is determined by a set of structural factors such as the level of development, the sectoral origin of income and the degree of monetization of the economy.

In contrast, in this paper we adopt stochastic frontier analysis techniques, which support a more intuitive-and potentially more policy-relevant-measure of tax potential and effort. Stochastic frontier analysis can be used to generate a stochastic tax frontier, which defines an estimated maximum potential tax-to-GDP ratio for a given set of determinant "inputs" and environmental factors.

\section{The Methodological Approach}

In the contemporary economic literature, the two methods of assessing the fiscal potential found are based mainly on estimates based on panel data. The first method of valuation consists in estimating an equation of the tax revenue ratio according to a set of variables considered as determining. The ratio predicted by the regression is the fiscal potential and the remainder of the equation represents the tax effort [12]. The second evaluation method consists in using the stochastic frontier estimation technique. This method is similar to the first one except that it breaks down the error term into two independent components. The first error term is assumed to follow a normal centered law, while the second follows a normal law strictly positive. The choice of the stochastic frontier estimation technique in this paper is based on three major elements: 1) the robustness of this method, indeed, it uses the rigor of statistical and econometric analysis to 
predict the level of potential sampling in view of the economic structure of the country; 2) countries with different levels of development or similar economic structures, the panel approach isolates country effects and; 3) the existence of numerous studies that have implemented this approach.

\subsection{The Analysis Model}

The models used in estimating tax potential are part of the empirical studies on the determinants of tax revenues. Several models are presented in studies that try to show the position of the key structural variables among the others suggested by the literature. The approach adopted in this study is inspired is inspired by the stochastic frontier model developed by Aigner, Lovell and Schmidt [23], Battese and Coelli [24] [25], Kumbhakar and Lovell [26] and Greene [27], and it is written as bellow:

$$
Y_{i t}=f\left(X_{i t}, \not \beta\right)+\varepsilon_{i t}
$$

with $\varepsilon_{i t}=\vartheta_{i t}-\mu_{i t}$.

$Y_{i t}$ represents the tax levy rate (Prefisc); $X_{i t}$ the vector of explanatory variables, $\beta$ the parameters to estimate, and $\varepsilon_{i t}$ the error term decomposed in $\vartheta_{i t}$ the white noise of the regression and $\mu_{i t}$ the term of ineffectiveness.

Following a linearization of the equation we obtain:

$$
Y_{i t}=\beta_{0}+\sum_{i=1}^{k} \beta_{i} X_{i t}+\vartheta_{i t}-\mu_{i t}
$$

We can deduce:

$$
\text { Presfisc }_{i t}=\beta_{0}+\sum_{i=1}^{k} \beta_{i} X_{i t}+\vartheta_{i t}-\mu_{i t}
$$

The stochastic frontier technique gives the maximum level of revenue that can be recovered by the economy given its different characteristics. The origin of this method comes from Farrel's [28] production frontier estimates. In addition, the term inefficiency of the stochastic boundary concerns only a failure resulting from the suboptimal behavior of the firm. On the other hand, for the estimation of the fiscal potential, the term inefficiency incorporates both technical and hazard inefficiency [29] [30]. The level of technical efficiency of individual $i$ at time $t$ is the ratio of actual performance to potential yields [26]. The technical efficiency in the stochastic frontier production function as part of the stochastic frontier tax function is the fiscal effort, which is obtained as the ratio of actual tax revenue to stochastic border tax revenue (which is the fiscal capacity).

\subsection{Choice of Variables and Expected Sign}

The variables used in the literature for potential analysis are diverse. For our study we retain those frequently used in studies.

The tax pressure variable (TXP) represents the share of tax revenue in GDP. It is an indicator of revenue mobilization. It is used in this study as a dependent variable to predict the fiscal potential of countries. 
The GDP per capita variable (GDPCAP) is a structural variable that reflects the level of income and then used to approximate the level of development of the economy. Brun et al. [4], Senou [16] and Bousselhami et al. [20] use it in several ways. Either to determine the significance of the levy on income. Or under the assumption that the more a country is developed the more the country has a resource mobilization capacity. A positive sign is expected for this variable.

The degree of openness (DOPEN) makes it possible to know whether the foreign exchanges are favorable to the tax levy. In addition, this variable is positively influenced by the fact that international transactions are easier to tax and more important for the developing country [3]. A positive sign of the variable is expected.

The degree of monetization measured by the ratio M2/GDP allows us to examine the relationship between the level of financial transactions and the tax levy. Broad money (as a share of GDP) has a significant positive effect on the fiscal potential, suggesting that a highly monetized economy would mobilize more tax revenue than a less monetized one.

Agricultural Added Value (AVGRI) is the share of agriculture in the economy. However, the agricultural sector is difficult to tax because of many unrecorded activities [19], so a negative relationship is expected.

\subsection{Data and Estimation Techniques}

The data used are drawn from the databases of the World Development Indicators (WDI) [31] and the Central Bank of West African States (CBWAS) [32]. They cover the period 1990 to 2017. The choice of this period is linked to the availability of the model's variables data. The tests will be carried out on the eight countries of the WAEMU zone (Table 1).

\subsection{Estimation Method}

For our analysis, we will use the panel estimation techniques. First, we performed the preliminary tests of unit root tests and the cointegration test.

Subsequently, we estimate the stochastic border model of the sampling rate (Equation (4)):

$$
\operatorname{Presfisc}_{i t}=\beta_{0}+\sum_{i=1}^{k} \beta_{i} X_{i t}+\vartheta_{i t}-\mu_{i t}
$$

Table 1. Variable dictionary.

\begin{tabular}{cccc}
\hline Variables & Definitions & Formula & Source \\
\hline TXP & Tax revenue on the GDP & Tax revenue/GDP & CBWAS \\
GDPCAP & Logarithm of GDP per capita & Log (GDP/inhabitant) & WDI \\
DOPEN & The degree of openness & (Import + Export)/GDP & WDI \\
AVGRI & Agricultural added value in GDP & AV Agricultural/GDP & WDI \\
M2/GDP & Money supply relative to GDP & M2/PIB & WDI \\
\hline
\end{tabular}


The dependent variable is the tax rate. Vector $X$ groups together the structural determinants of the tax pressure used in this study: the log of GDP per capita, agricultural added value, the rate of trade openness and the degree of monetization.

Equation (4) thus estimated represents the tax pressure model. Then, we determine the optimal tax rate (or fiscal potential), which is the predicted value of the dependent variable.

\subsection{Preliminary Tests: Panel Unit Root Tests}

The stationarity tests are prior to the analysis of the estimates in panel data in order to avoid false regressions in case of presence of unit root. In order to make a rigorous analysis, we will use two types of tests namely that of Im, Pesaran and Shin et al. [33] and Levin, Lee and Chu [34].

The results of these tests recorded in Table 2 indicate that only the tax pressure rate variable is stationary at level, all the other variables are stationary in first difference.

\section{Results and Interpretations}

This section presents the main results of the econometric estimations and makes an analysis between the optimal tax pressure and that observed in order to formulate economic policy recommendations to the WAEMU countries.

\subsection{The Stylized Facts on the Tax Pressure in the WAEMU}

West African tax systems are characterized by a very low level of domestic levy, a very strong pressure on door taxation and also by the unequal distribution of their burden on the income of taxpayers. In the WAEMU, duties and taxes on imports and exports represents on average one-quarter (24\%) of tax revenues, although with large disparities between countries. Direct taxes, consisting of taxes on corporations and individuals, remain the weak point in the mobilization of tax.

Table 2. Unit root tests.

\begin{tabular}{ccccc}
\hline & \multicolumn{2}{c}{ LLC } & \multicolumn{2}{c}{ IPS Decision } \\
\hline \multirow{2}{*}{ TXP } & Level & Difference & Level & Difference \\
& -7.36 & - & -1.99 & $-\mathrm{I}(0)$ \\
GDPCAP & $(0.00)$ & & $(0.02)$ & \\
& -7.12 & -13.42 & -1.24 & $-7.26 \mathrm{I}(1)$ \\
DOPEN & $(0.00)$ & $(0.00)$ & $(0.11)$ & $(0.00)$ \\
& -5.43 & -11.91 & -0.49 & $-5.98 \mathrm{I}(1)$ \\
AVGRI & $(0.47)$ & $(0.00)$ & $(0.31)$ & $(0.00)$ \\
& -6.40 & -14.12 & -0.91 & $-8.15 \mathrm{I}(1)$ \\
M2/GDP & $(0.03)$ & $(0.00)$ & $(0.18)$ & $(0.00)$ \\
& -4.90 & -12.76 & 1.34 & $-6.43 \mathrm{I}(1)$ \\
\hline
\end{tabular}

Source: Author, Notes: (...) probability. 
In this dynamic (Figure 1), the WAEMU commission works in collaboration with the national tax administrations for a better follow-up of tax transition. However, a decade after its implementation, the level of tax revenue mobilization in WAEMU countries remains low.

The analysis of the Figure 1 shows that over the period 2013-2017, only 50\% of the WAEMU countries achieved a level of revenue mobilization exceeding 1000 billion FCFA per year for needs of more than 2000 billion per year expressed in countries' development plans and growth strategies.

In general, tax issues in the WAEMU (Figure 2), beyond the internal situations of each country, arise today in regional terms, because in a process of globalization of the economy, the micro-states that constitute these countries can't get out of a process of integration and regional cooperation.

Figure 2 shows an overall change in the level of tax pressure in the WAEMU since the beginning of the 2000s. In general, the Union countries have significantly improved the level of tax resource mobilization from $14.66 \%$ to $15.95 \%$ of GDP in 2016, the highest level of the period. Moreover, this poor performance hides disparities between countries.

Thus, Figure 3 shows that in 2017, only Togo respects the WAEMU convergence criteria by achieving a tax revenue ratio on GDP superior or equal to $20 \%$. On the other hand, the other seven countries are still lagging behind with tax pressure rates ranging from $9 \%$ (Guinea Bissau) to $18 \%$ (Niger).

In terms of tax revenue mobilization, it seems that in the WAEMU countries, despite the efforts made to ensure the balance of the macroeconomic framework, there are other issues that hinder the process of mobilizing domestic resources, particularly the informal sector quite developed, the weight of tax exemptions in the agricultural sector and illicit financial flows.

Given these results, it is wise for the WAEMU economies to know their fiscal potential to identify the best economic policies to implement to increase efficiency in revenue mobilization or reduce the tax burden, sources of undesirable and counterproductive social effects.

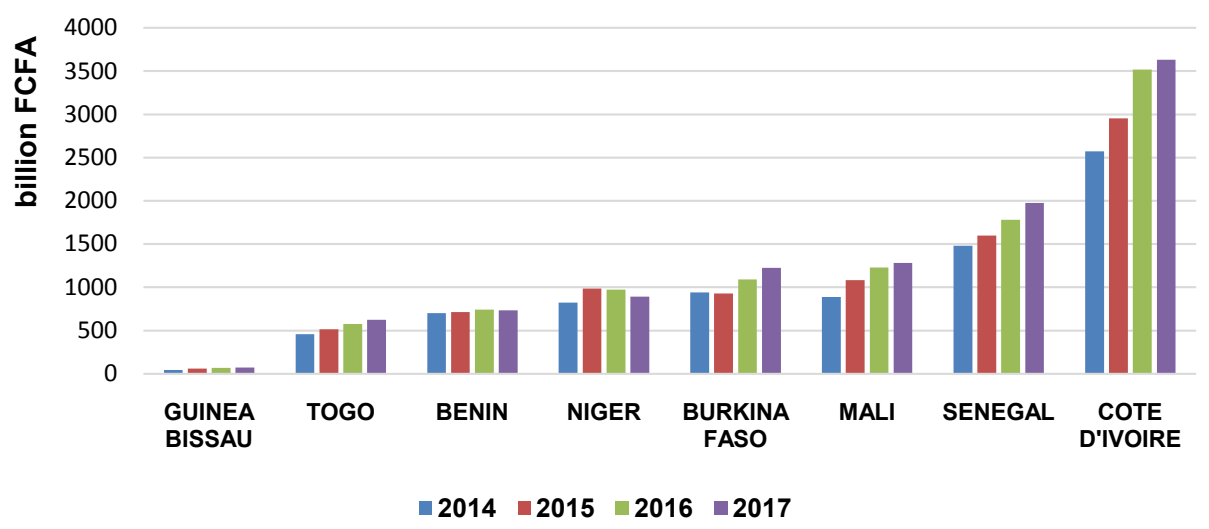

Figure 1. Tax revenue of WAEMU countries over the 2012-2017 period. Source: Author with CBWAS data [32]. 


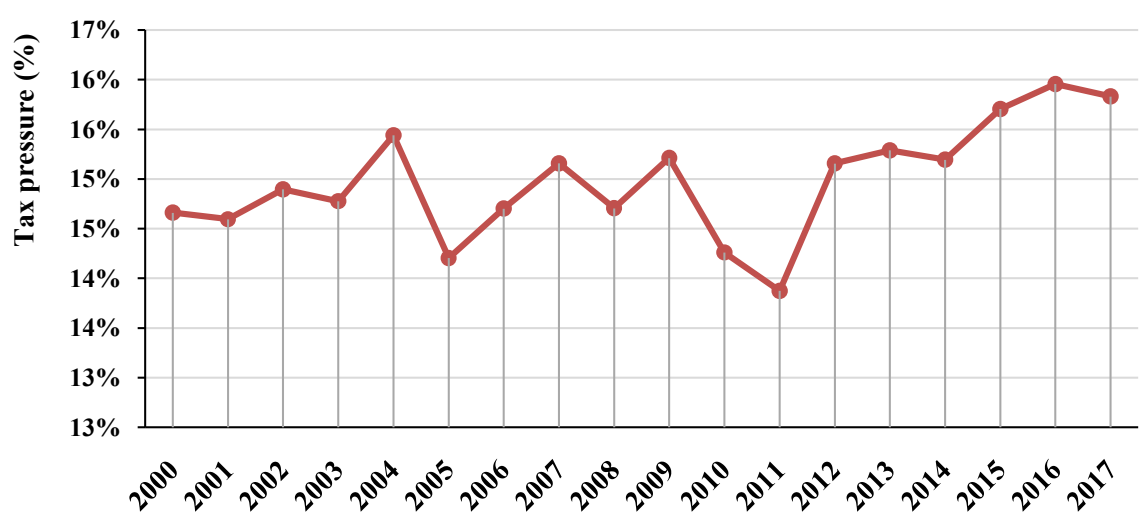

Figure 2. Evolution of the tax pressure rate in the WAEMU. Source: Author with CBWAS data [32].

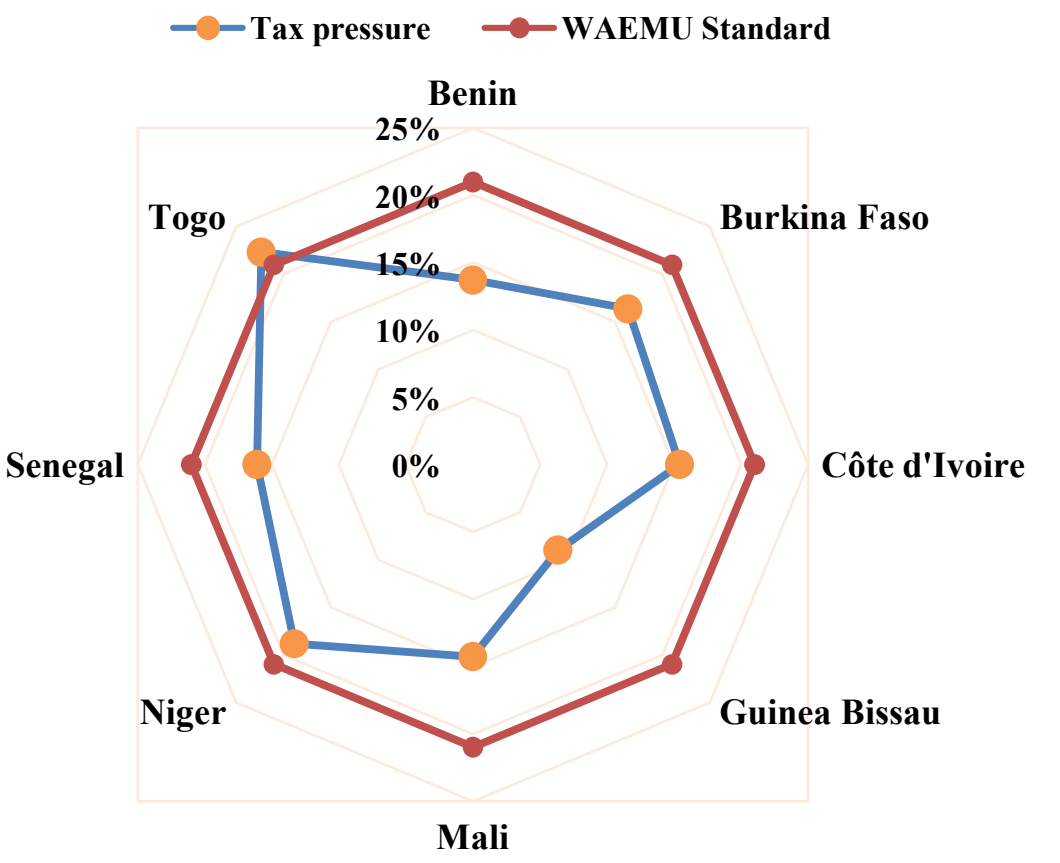

Figure 3. WAEMU countries' tax pressure in 2017. Source: Author with CBWAS data [32].

\subsection{Description of the Data}

The descriptive statistics of the variables, presented in Table 3, show that the average of the total tax revenue in percentage is of $12.54 \%$ for the WAEMU countries over the period 1990-2017. This rate remains low and far from the Community norm of $20 \%$. The maximum rate of $23.09 \%$ was recorded in 2015 in Niger, while Guinea-Bissau recorded the minimum over the period (i.e. $1.16 \%$ of GDP) in 1994. The observation of the structural variables can make it possible to have an idea of the poor fiscal performance of the countries of the sub-region.

In fact, agriculture, essentially informal, occupies an important place in the economies of these countries with an average added value of $32.19 \%$ of GDP, over the period 1990-2017. This sector escapes the tax administration, and can 
Table 3. Descriptive statistics of estimation variables.

\begin{tabular}{cccccc}
\hline Variable & Obs & Mean & Std. Dev. & Max & Min \\
\hline Tax pressure & 224 & 12.54 & 4.24 & 23.09 & 1.16 \\
GDP per capita & 224 & 278,186 & 163,841 & 967,699 & 8103 \\
Agricultural added value & 224 & 32.19 & 9.96 & 61.42 & 11.88 \\
Degree of openness & 224 & 60.66 & 17.82 & 125.03 & 28.37 \\
Degree of monetization & 224 & 26.40 & 9.71 & 68.87 & 6.55 \\
\hline
\end{tabular}

Source: Author.

partly justify the poor fiscal performance of the countries of the union. In addition, GDP per capita, which is an indicator of the level of development, remained low with an average of 278,186 FCFA over the period. The degree of monetization measured by the ratio M2 on GDP, and the degree of commercial openness are, on average, 26.4 and 60.6 respectively as a percentage of GDP.

\subsection{Estimation of the Fiscal Potential of the WAEMU Countries}

As a result of the preliminary tests, we can therefore estimate the fiscal potential according to the following model:

$$
\mathrm{TXP}_{i t}=\beta_{0}+\beta_{1} \mathrm{GDPCAP}_{i t}+\beta_{2} \mathrm{DOPEN}_{i t}+\beta_{3} \mathrm{AVAGRI}_{i t}+\beta_{3} \mathrm{M} 2 / \mathrm{GDP}_{i t}+\vartheta_{i t}-\mu_{i t}
$$

The estimation of the tax potential allows us to measure the impact of structural factors on the tax pressure. Table 4 provides information on the results of the estimation of the stochastic frontier tax function for WAEMU countries. The estimate is made considering the inefficiency of the term in tax mobilization to follow the truncated normal distribution of Battese and Coelli [23] [24]. Our estimates incorporate the TVD option (Time-varying decay inefficiency model) that allows you to specify a time variable. The term inefficiency is modeled as a truncated normal random variable multiplied by a time function. In this model, the efficiency effects are modeled as follows:

$$
u_{i t}=\exp \left\{-\eta(t-T)_{i}\right\} u_{i}
$$

when $\eta>0$, the degree of inefficiency decreases with time; when the degree of efficiency increases over time.

The total variance $\left(\sigma^{2}\right)$ is significantly different from 0 at the $1 \%$ threshold. The variance of the inefficiency component is equal to: $\sigma_{\mu}^{2}=\gamma \sigma^{2}=0.235$ and that of the pure random component is: $\sigma_{s}^{2}=\sigma^{2}-\sigma_{\mu}^{2}=1.886$. This means that the tax differences observed in relation to the fiscal frontier are due not only to technical inefficiency but also to the pure random component. The stochastic frontier model is therefore more suitable than the deterministic model. Moreover, the differences are mainly explained by the pure random component $\left(\delta_{s}^{2}>\delta_{\mu}^{2}\right)$. Finally, $\eta>0$, highlights the decay over time of the degree of inefficiency in the mobilization of fiscal resources in the WAEMU countries.

The results show that per capita GDP positively and significantly influences 
Table 4. Estimation of the fiscal potential of the WAEMU countries.

\begin{tabular}{cc}
\hline Explanatory Variables & Dependent Variable (Tax Pressure) \\
Real GDP per capita & Border \\
\hline Agricultural Added Value (\% of GDP) & $3.436^{* *}(1.559)$ \\
Commercial opening & $-0.0738^{*}(0.041)$ \\
Money supply (M2 as a \% of GDP) & $-0.0479^{* *}(0.022)$ \\
Constant & $0.0069(0.029)$ \\
& $19.66^{* * *}(1.477)$ \\
Sigma square $\left(\mathcal{f}^{2}\right)$ & \\
Gamma $(\gamma)$ & $2.121^{* * *}(0.325)$ \\
Mu $(\mu)$ & $0.111(0.619)$ \\
Eta $(\eta)$ & $4.449^{* * *}(1.630)$ \\
Observations & $0.0334^{* * *}(0.006)$ \\
Number of countries & 216 \\
Log likelihood & 8 \\
Wald chi2 $(4)$ & -471.66 \\
\hline
\end{tabular}

Standard errors in parentheses ${ }^{* *} \mathrm{p}<0.01,{ }^{* *} \mathrm{p}<0.05,{ }^{*} \mathrm{p}<0.1$. Source: Author.

the tax pressure. The degree of trade openness and agricultural added value have a significantly negative influence. More specifically, a 1 percentage point increase in the Real GDP per capita leads to an increase in the tax pressure of 3.4 percentage points, while the increase in the degree of trade openness and the agricultural added value of a unit decrease the tax pressure respectively by 0.07 and 0.04 .

The added value of agriculture as a surrogate for the ease of tax collection has a negative and significant effect, which is explained by the fact that in most countries agriculture is tax-exempt and very informal. The share of the agricultural sector is estimated at about $32.19 \%$ over the period in the sub region, and is growing more in the informal sector. Most of the actors come from rural areas where fiscal knowledge is lacking. This sector therefore requires a reorganization to facilitate its imposition. The negative sign associated with trade opening is certainly unexpected but can be justified by a fiscal transition with a decline trend in door tax revenues.

The effect of the change in the share of M2 money supply in GDP on the tax pressure is not significant. Thus, the degree of monetarization of the economy does not affect the ability of states to mobilize more resources. The result is contrary to the Karagoz [35] theory because the more an economy is monetarized, the more the economic transactions is developing, and the more the taxable matter is created. It is important to know that the degree of monetarization of the economy is a factor that strongly influences the public levy. This result can 
be explained by the low level of monetization and the rate of bank access, which is around $16.1 \%$ in 2016.

\subsection{Robustness Analysis: Addition of other Explanatory Variables}

This section makes a robustness analysis using other structural variables (informal sector share and industrial added value). The share of the informal sector is extracted from the Medina and Schneider base [36]. For reasons of colinearity we exclude the agricultural added value of this analysis.

The results are shown in Table 5. The analysis of the inefficiency parameters shows that the border model is robust. The total variance $\left(\sigma^{2}\right)$ is significantly different from 0 at the $1 \%$ threshold. The variance of the inefficiency component is equal to: $\sigma_{\mu}^{2}=\gamma \sigma^{2}=0.648$ and that of the pure random component is: $\sigma_{s}^{2}=\sigma^{2}-\sigma_{\mu}^{2}=1.472$. This means that the tax differences observed in relation to the fiscal frontier are due not only to technical inefficiency but also to the pure random component $\left(\delta_{s}^{2}>\delta_{\mu}^{2}\right) \cdot \eta=0.038>0$ which means that the degree of inefficiency in the mobilization of fiscal resources decreases over time.

The results are largely consistent with the variables. Thus, the degree of monetization (M2), product per capita and industrial added value positively influence the tax pressure while the degree of trade openness has a negative impact. Like agricultural added value, the share of the informal sector negatively influences, but not significantly, the tax pressure in the WAEMU countries.

In fact, the informal sector occupies a large part of the population in the WAEMU area, with a contribution to GDP estimated at an average of $41.37 \%$ over the period. This importance of the informal sector is a constraint in the

Table 5. Robustness analysis.

\begin{tabular}{|c|c|}
\hline Explanatory Variables & Dependent variable (Tax Pressure) \\
\hline \multicolumn{2}{|l|}{ Border } \\
\hline Real GDP per capita & $3.507^{\star}(1.791)$ \\
\hline Industrial Added Value (\% GDP) & $0.0196(0.0747)$ \\
\hline Commercial opening & $-0.0395^{\star}(0.0238)$ \\
\hline Money supply (M2 as a \% of GDP ) & $0.0505(0.0489)$ \\
\hline Share of the informal sector (\% GDP) & $-0.0464(0.0709)$ \\
\hline Constant & $18.61^{\star \star \star}(1.360)$ \\
\hline \multicolumn{2}{|l|}{ Inefficiency } \\
\hline Sigma carré $\left(\delta^{\mathscr{R}}\right)$ & $2.120^{\star * *}(0.392)$ \\
\hline $\operatorname{Gamma}(\gamma)$ & $0.306(0.686)$ \\
\hline $\mathrm{Mu}(\mu)$ & $3.786^{\star \star}(1.682)$ \\
\hline $\operatorname{Eta}(\eta)$ & $0.0383^{* * *}(0.00697)$ \\
\hline Observations & 192 \\
\hline Number of Pays & 8 \\
\hline Log likelihood & -410.65 \\
\hline
\end{tabular}

Standard errors in parentheses ${ }^{* *} \mathrm{p}<0.01,{ }^{* *} \mathrm{p}<0.05,{ }^{*} \mathrm{p}<0.1$. Source: Author. 
mobilization of fiscal resources because many activities are outside the tax administration. Reforms are necessary to bring the various actors to migrate to the formal.

\subsection{Comparative Analysis between the Tax Potential and the Effective Tax Pressure}

As a result of our estimates, we determine the tax potential as the predicted level of the levy and the trends are observed in Figure 4.

The analysis of the evolution of the tax pressure and the potential shows characteristic facts about the WAEMU economies. Indeed, Figure 4 shows that the tax potential is higher than the effective tax pressure in 6 out of 8 countries. It shows that the fiscal potential is not fully mobilized and that these countries (Benin, Burkina Faso, Côte d'Ivoire, Guinea Bissau, Mali and Senegal) have fiscal space that remains to be exploited.

Niger and Togo are the countries that have made an exception and are those that have, during the period 1990-2017, respected the $20 \%$ community norm in terms of taxation recommended by WAEMU. This can be justified by the introduction of the tax reforms harmonized by these countries and by an economic situation resistant to the various external shocks. Among other things, the countries of the Union are making efforts but are generally confronted with a vast informal sector which is largely exempt from taxation. Also, there are recessions caused by instability in each country and dependence on external resources including public aid for development.

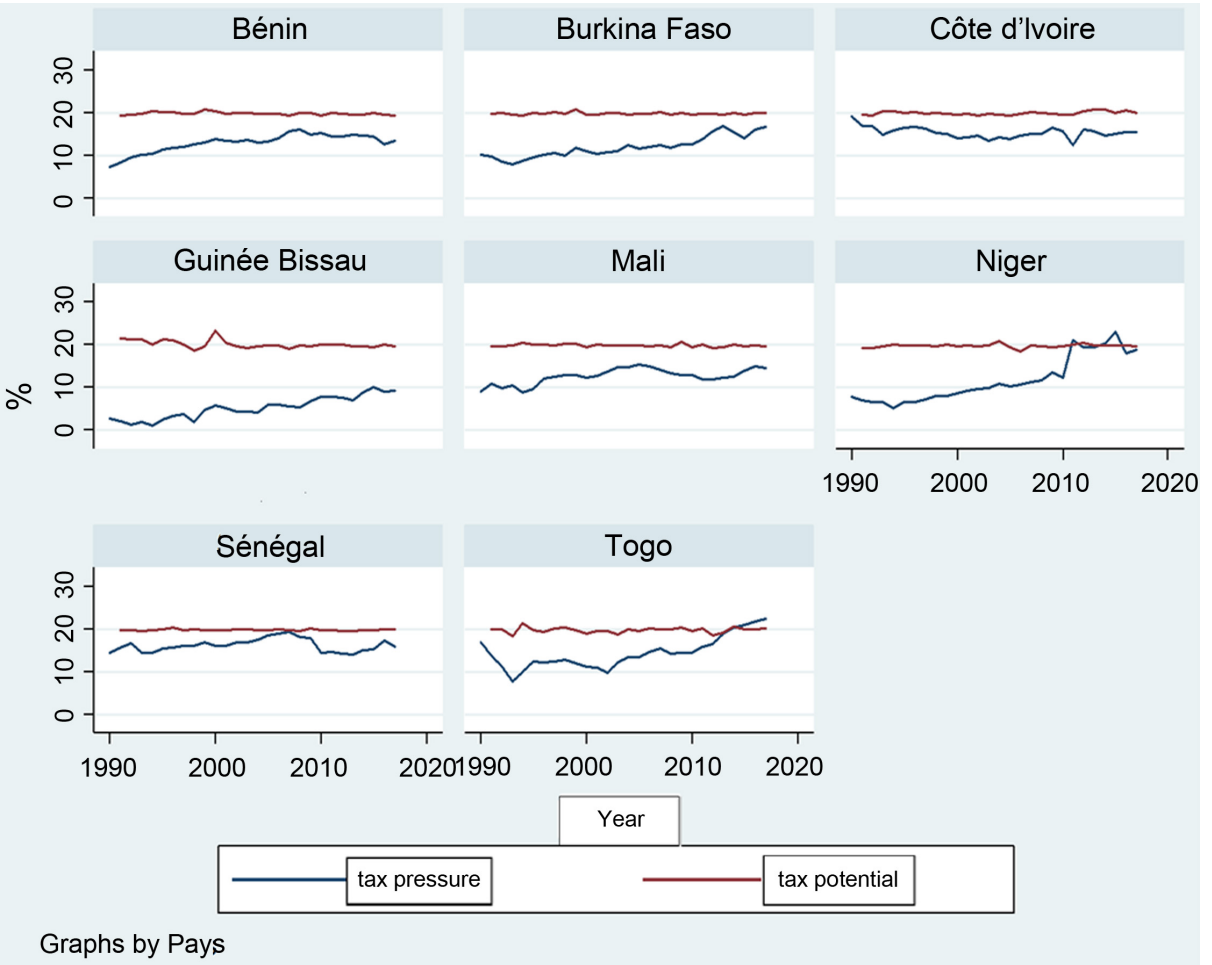

Figure 4. Evolution of the tax pressure and the tax potential. Source: Author. 


\subsection{Analysis of the Tax Effort}

The analysis of the tax effort reflects the actual level of levy compared to the potential levy. We use the effective tax pressure, expressed as a percentage of the contributive capacity as a measure of fiscal effort, as demonstrated by Kumbhaker and Lovell [26] and Pessino and Fenochietto [30]. When the effort is more than 1 , this means that the actual sample is superior to the potential sample while a lower value corresponds to a sample that is below to the potential.

Table 6 shows that, on average, over the period 1990-2017, all countries have remained far from their fiscal potential. Disparities exist between countries, and tax efforts vary, on average, from 27\% (Guinea-Bissau) to 82\% (Senegal). Our results are comparable to those of Ndiaye and Korsu [37] who find tax efforts ranging from $35 \%$ (Guinea-Bissau) to $84 \%$ (Senegal) during the decade 2000-2010.

In addition, through Figure 4 and Appendix 1, we observe a significant gap between the effective tax pressure and the tax potential for different countries of the union, for most of the time. Only Niger, Senegal and Togo have at times reached their harvesting potential. Niger and Togo are the best performers in the area in terms of resource mobilization. Niger reaches its potential in 2012, 2014 and 2015. Since 2014, Togo has exceeded its potential and presents a fiscal effort superior than unity. As a result, economic policy and the introduction of tax reforms have been conducive to the mobilization of fiscal resources and have improved the recovery of public resources. However, other countries remain inefficient in resource mobilization.

\section{Conclusions}

The mobilization of tax revenues is one of the most pressing challenges facing the countries of the West African Economic and Monetary Union (WAEMU). In fact, tax revenues are a major factor in the development strategies of these countries and, especially in economic life, in the effective provision of public

Table 6. Average tax pressure, tax potential and tax gap.

\begin{tabular}{cccc}
\hline \multirow{2}{*}{ COUNTRY } & \multicolumn{3}{c}{ Average over the period 1990-2017 } \\
\cline { 2 - 4 } & Fiscal pressure & Fiscal potential & Fiscal effort \\
\hline Benin & 13.13 & 19.82 & 0.66 \\
Burkina & 12.01 & 19.79 & 0.61 \\
Côte d'Ivoire & 15.20 & 19.88 & 0.76 \\
Guinea-Bissau & 5.32 & 20.15 & 0.27 \\
Mali & 12.76 & 19.84 & 0.64 \\
Niger & 11.87 & 19.74 & 0.60 \\
Senegal & 16.24 & 19.78 & 0.82 \\
Togo & 14.26 & 19.74 & 0.72 \\
\hline
\end{tabular}

Source: Author. 
services. However, a very high level of tax pressure discourages taxpayers and leads to economic distortions.

Thus, the stylized facts show that, despite the efforts of the States in terms of tax revenue mobilization, WAEMU remains the sub-region where the revenue/GDP ratio remains the lowest. Therefore, the issue of tax revenue mobilization within the WAEMU zone was the subject of our analysis in this article, based on the structural factors of tax mobilization.

Using a stochastic border model as a panel, our estimates highlight the assessment of the fiscal potential and the role played by structural factors. The results show that the level of development has a positive and significant effect on the tax pressure, while the share of agricultural added value and trade opening has a negative and significant effect. Moreover, the tax potential varies according to the country and the Community standard is not respected on average by all countries over the period concerned. The same is true of the effort made to mobilize resources, even though Niger and Togo are showing very appreciable results over the last few years.

Therefore, the improvement of fiscal resources within the WAEMU zone is a process designed to design, with a community-specific levy system and defined according to the economic and social development strategy in order to be able to collect taxes from the WAEMU zone. In addition, the agricultural added value that significantly and negatively affects the fiscal potential, as this sector escapes taxation (exemption), as well as climatic hazards. Finally, to benefit from the advantages of trade openness and to face international competition, the countries of the zone must intensify efforts in their process of industrialization by micro-industries, to reorient industrial policy.

Two main contributions can be selected from this research. First, this research has shown that raising the minimum tax pressure rate from $17 \%$ to $20 \%$ in the WAEMU in 2015 is empirically valid. Moreover, the analysis shows that the countries of the Union as a whole cannot reach or even exceed this minimum threshold in view of the structural characteristics of the economies of the Union. Secondly, this study has shown that for all WAEMU countries, agriculture contributes very little and even negatively to tax revenues, except in Togo where its contribution is strong with a tax ratio (51.4\%). In the end, it is fundamental to consider, from the empirical results, two lines of research to improve this study among others. This is on the one hand the evaluation of informal GDP and introduces it into the model in order to obtain more robust results. On the other hand, this research could be improved by integrating measures of inequality, well-being of individuals and distribution of their income through a computable general equilibrium model.

\section{Conflicts of Interest}

The author declares no conflicts of interest regarding the publication of this paper. 


\section{References}

[1] Culpeper, R. and Bhushan, A. (2010) Domestic Resource Mobilization in Africa: An Overview. The North-South Institute. http://www.nsi-ins.ca/content/download/DRM_Synthesis_V5.pdf

[2] Diarra, S. (2013) Chocs et Mobilisation des Recettes Publiques dans les Pays en Développement. Thèse de Doctorat, Université d'Auvergne, Clermont-Ferrand.

[3] Wade, A. (2015) Policy-Mix et croissanceéconomiquedans la zone UEMOA. Economies et finances. Université d'Auvergne, Clermont-Ferrand I.

[4] Brun, J.F., Chambas, G. and Combes, J.L. (2006) Recettes publiques des pays en développement: Méthodes d'évaluations. (CERDI), STATECO, No. 100.

[5] Mirrlees, J.A. (1971) An Exploration in the Theory of Optimal Income Taxation. Review of Economic Studies, 38, 175-208. https://doi.org/10.2307/2296779

[6] Laffer, A.B. (1981) Supply-Side Economics. Financial Analysts Journal, 37, 29-44. https://doi.org/10.2469/faj.v37.n5.29

[7] Barro, J.R. (1990) Government Spending in a Simple Model of Endogenous Growth. Journal of Political Economy, 98, 103-125. https://doi.org/10.1086/261726

[8] Saez, E. (2001) Using Elasticities to Derive Optimal Income Tax Rates. Review of Economic Studies, 68, 205-229. https://doi.org/10.1111/1467-937X.00166

[9] Bousselhami, N. and Hamzaoui, M. (2018) Morocan Tax Potential: Econometric Analysis through the Tax Effort. Turkish Economic Reviews, 5, 22-32.

[10] Branson, J. and Lovell, C.A. (2001) A Growth Maximising Tax Structure for New Zealand. International Tax and Public Finance, 8, 129-146. https://doi.org/10.1023/A:1011216618163

[11] Scully, G.W. (1995) The Growth Tax' in the United States. Public Choice, 85, 71-80. https://doi.org/10.1007/BF01047902

[12] Chambas, G. and Brun, J.F. (2010) Evaluation du potentiel de recettes publiques. Banque Africaine du développement.

[13] Gupta, A.S. (2007) Determinants of Tax Revenue Efforts in Developing Countries. International Monetary Fund, Working Paper, No. 07/184. https://doi.org/10.5089/9781451867480.001

[14] Keho, Y. (2010) Détermination d'un Taux de Pression Fiscale Optimal en Côte d'Ivoire. Politique Economique et Développement No. 04/2009 de la CAPEC.

[15] Addison, T. and Jorgen, L. (2012) The Determinants of Tax Revenue in Sub-Saharan Africa. Manuscript en Örebro University Library. http://oru.diva-portal.org/smash/get/diva2:570456/FULLTEXT01.pdf

[16] Senou, B.M. (2014) Un essai d'analyse du potentiel fiscal du Bénin. Revue d Economie Théorique et Appliquée, 4, 181-202.

[17] Ba, A. and Sakrya, Y. (2016) Evaluation du potentiel fiscal pour le Sénégal. Direction de la Prévision et des Etudes Economiques (DPEE), Document d'étude (34).

[18] Saibu, O.M. (2015) Optimal Tax Rate and Economic Growth: Evidence from Nigeria and South Africa. Euro Economica, 1.

[19] Amgain, J. (2017) Estimating Optimal Level of Taxation for Growth Maximization in Asia. Applied Economics and Finance, 4, 47-55.

[20] Bousselhami, N. and Hamzahoui, M. (2017) Impact de la fiscalité sur la croissance économique du Maroc. European Scientific Journal, 13, 104-127.

[21] Bird, R.M., Vasquez, J.M. and Torgler, B. (2014) Societal Institutions and Tax Effort 
in Developing Countries. Annals of Economics and Finance, 15, 185-230.

[22] Stotsky, J.G. and Woldmariam, A. (1997) Tax Effort in Sub-Saharan Africa. International Monetary Fund, Working Paper, No. 97/107. https://doi.org/10.5089/9781451852943.001

[23] Aigner, D.J., Lovell, C.A. and Schmidt, P. (1977) Formulation and Estimation of Stochastic Frontier Production Function Models. Journal of Econometrics, 6, 21-37. https://doi.org/10.1016/0304-4076(77)90052-5

[24] Battese, G.E. and Coelli, T.J. (1992) Frontier Production Functions, Technical Efficiency and Panel Data: With Application to Paddy Farmers in India. Journal of Productivity Analysis, 3, 153-169. https://doi.org/10.1007/BF00158774

[25] Battese, G.E. and Coelli, T.J. (1995) A Model for Technical Inefficiency Effects in a Stochastic Frontier Production Function for Panel Data. Empirical Economics, 20, 325-332. https://doi.org/10.1007/BF01205442

[26] Kumbhakar, S.C. and Lovell, K. (2000) Stochastic Frontier Analysis. Cambridge University Press, Cambridge. https://doi.org/10.1017/CBO9781139174411

[27] Greene, W. (2005) Fixed and Random Effects in Stochastic Frontier Models. Journal of Productivity Analysis, 23, 7-32. https://doi.org/10.1007/s11123-004-8545-1

[28] Farrel, J.M. (1957) The Measurement of Production Efficiency. Journal of Royal Statistics, Series, 120, 253-290.

[29] Alfirman, L. (2003) Estimating Stochastic Frontier Tax Potential: Can Indonesian Local Governments Increase Tax Revenues under Decentralization? Centre for Economic Analysis, Working Paper, 03-19.

[30] Pessino, C. and Fenochietto, R. (2010) Etermining Countries' Tax Effort. Hacienda Pública Española. Revista de Economía Pública, 195, 61-68.

[31] World Development Indicators (2018).

[32] CBWAS Data (2018). https://edenpub.bceao.int/rapport.php

[33] Im, K.S., Pesaran, M.H. and Shin, Y. (2003) Testing for Unit Roots in Heterogeneous Panels. Journal of Econometrics, 115, 53-74. https://doi.org/10.1016/S0304-4076(03)00092-7

[34] Levin, A., Lin, C.-F. and Chu, C.-S.J. (2002) Unit Root Tests in Pane Data: Asymptotic and Finite-Sample Properties. Journal Economic, No. 108, 1-24. https://doi.org/10.1016/S0304-4076(01)00098-7

[35] Karagöz, K. (2013) Determinants of Tax Revenue: Does Sectorial Composition Matter? Journal of Finance, Accounting and Management, 4, 50-63.

[36] Medina, L. and Schneider, F. (2018) Shadow Economies around the World: What Did We Learn over the Last 20 Years? African Department, IMF Working Papers $18 / 17$.

[37] Ndiaye, M.B.O. and Korsu, R.D. (2011) Tax Effort in ECOWAS Countries. West African Monetary Agency (WAMA). 


\section{Appendix 1}

Tax pressure, tax potential and tax gap in the WAEMU countries from 1991 to 2017

\begin{tabular}{|c|c|c|c|c|c|c|c|}
\hline \multicolumn{4}{|c|}{ BENIN } & \multicolumn{4}{|c|}{ BURKINA FASO } \\
\hline Years & $\begin{array}{c}\text { Fiscal } \\
\text { Pressure }\end{array}$ & $\begin{array}{c}\text { Fiscal } \\
\text { Potential }\end{array}$ & Fiscal Effort & Years & $\begin{array}{c}\text { Fiscal } \\
\text { Pressure }\end{array}$ & $\begin{array}{c}\text { Fiscal } \\
\text { Potential }\end{array}$ & Fiscal Effort \\
\hline 1991 & 8.42 & 19.42 & 0.43 & 1991 & 9.81 & 19.66 & 0.50 \\
\hline 1992 & 9.66 & 19.58 & 0.49 & 1992 & 8.48 & 19.91 & 0.43 \\
\hline 1993 & 10.22 & 19.84 & 0.51 & 1993 & 7.89 & 19.47 & 0.41 \\
\hline 1994 & 10.35 & 20.35 & 0.51 & 1994 & 8.81 & 19.43 & 0.45 \\
\hline 1995 & 11.36 & 20.16 & 0.56 & 1995 & 9.57 & 19.90 & 0.48 \\
\hline 1996 & 11.81 & 20.08 & 0.59 & 1996 & 10.09 & 19.81 & 0.51 \\
\hline 1997 & 11.99 & 19.75 & 0.61 & 1997 & 10.48 & 20.07 & 0.52 \\
\hline 1998 & 12.61 & 19.74 & 0.64 & 1998 & 10.03 & 19.66 & 0.51 \\
\hline 1999 & 13.01 & 20.78 & 0.63 & 1999 & 11.89 & 20.73 & 0.57 \\
\hline 2000 & 13.94 & 20.35 & 0.68 & 2000 & 10.92 & 19.55 & 0.56 \\
\hline 2001 & 13.50 & 19.72 & 0.68 & 2001 & 10.34 & 19.57 & 0.53 \\
\hline 2002 & 13.27 & 20.00 & 0.66 & 2002 & 10.78 & 19.92 & 0.54 \\
\hline 2003 & 13.53 & 20.00 & 0.68 & 2003 & 11.05 & 20.04 & 0.55 \\
\hline 2004 & 13.04 & 19.67 & 0.66 & 2004 & 12.46 & 19.59 & 0.64 \\
\hline 2005 & 13.18 & 19.80 & 0.67 & 2005 & 11.69 & 19.75 & 0.59 \\
\hline 2006 & 14.09 & 19.70 & 0.72 & 2006 & 11.91 & 19.77 & 0.60 \\
\hline 2007 & 15.61 & 19.34 & 0.81 & 2007 & 12.49 & 20.15 & 0.62 \\
\hline 2008 & 16.04 & 20.05 & 0.80 & 2008 & 11.87 & 19.50 & 0.61 \\
\hline 2009 & 14.93 & 19.93 & 0.75 & 2009 & 12.52 & 19.90 & 0.63 \\
\hline 2010 & 15.23 & 19.36 & 0.79 & 2010 & 12.72 & 19.55 & 0.65 \\
\hline 2011 & 14.50 & 20.04 & 0.72 & 2011 & 13.75 & 19.68 & 0.70 \\
\hline 2012 & 14.37 & 19.81 & 0.73 & 2012 & 15.63 & 19.70 & 0.79 \\
\hline 2013 & 14.77 & 19.47 & 0.76 & 2013 & 16.83 & 19.45 & 0.87 \\
\hline 2014 & 14.61 & 19.44 & 0.75 & 2014 & 15.46 & 20.02 & 0.77 \\
\hline 2015 & 14.54 & 19.98 & 0.73 & 2015 & 14.09 & 19.63 & 0.72 \\
\hline 2016 & 12.61 & 19.46 & 0.65 & 2016 & 16.04 & 20.00 & 0.80 \\
\hline 2017 & 13.46 & 19.42 & 0.69 & 2017 & 16.67 & 19.97 & 0.83 \\
\hline Ave. & 13.14 & 19.82 & 0.66 & Ave. & 12.01 & 19.79 & 0.61 \\
\hline \multicolumn{4}{|c|}{ CÔTE D'IVOIRE } & \multicolumn{4}{|c|}{ GUINEA-BISSAU } \\
\hline Years & $\begin{array}{c}\text { Fiscal } \\
\text { Pressure }\end{array}$ & $\begin{array}{c}\text { Fiscal } \\
\text { Potential }\end{array}$ & Fiscal Effort & Years & $\begin{array}{c}\text { Fiscal } \\
\text { Pressure }\end{array}$ & $\begin{array}{c}\text { Fiscal } \\
\text { Potential }\end{array}$ & Fiscal Effort \\
\hline 1991 & 16.90 & 19.58 & 0.86 & 1991 & 2.07 & 21.52 & 0.10 \\
\hline
\end{tabular}




\section{Continued}

\begin{tabular}{|c|c|c|c|c|c|c|c|}
\hline 1992 & 16.95 & 19.33 & 0.88 & 1992 & 1.29 & 21.26 & 0.06 \\
\hline 1993 & 14.77 & 20.37 & 0.73 & 1993 & 1.86 & 21.28 & 0.09 \\
\hline 1994 & 15.94 & 20.40 & 0.78 & 1994 & 1.16 & 20.02 & 0.06 \\
\hline 1995 & 16.41 & 19.88 & 0.83 & 1995 & 2.48 & 21.22 & 0.12 \\
\hline 1996 & 16.74 & 20.10 & 0.83 & 1996 & 3.37 & 21.13 & 0.16 \\
\hline 1997 & 16.24 & 19.75 & 0.82 & 1997 & 3.75 & 20.03 & 0.19 \\
\hline 1998 & 15.33 & 19.87 & 0.77 & 1998 & 1.89 & 18.69 & 0.10 \\
\hline 1999 & 15.06 & 19.71 & 0.76 & 1999 & 4.81 & 19.68 & 0.24 \\
\hline 2000 & 14.12 & 19.54 & 0.72 & 2000 & 5.88 & 23.37 & 0.25 \\
\hline 2001 & 14.24 & 19.81 & 0.72 & 2001 & 5.18 & 20.49 & 0.25 \\
\hline 2002 & 14.63 & 19.39 & 0.75 & 2002 & 4.29 & 19.65 & 0.22 \\
\hline 2003 & 13.38 & 19.76 & 0.68 & 2003 & 4.30 & 19.19 & 0.22 \\
\hline 2004 & 14.19 & 19.48 & 0.73 & 2004 & 4.21 & 19.61 & 0.21 \\
\hline 2005 & 13.88 & 19.32 & 0.72 & 2005 & 5.92 & 19.92 & 0.30 \\
\hline 2006 & 14.65 & 19.66 & 0.75 & 2006 & 5.97 & 19.78 & 0.30 \\
\hline 2007 & 15.06 & 20.10 & 0.75 & 2007 & 5.64 & 19.13 & 0.29 \\
\hline 2008 & 14.99 & 19.99 & 0.75 & 2008 & 5.40 & 19.92 & 0.27 \\
\hline 2009 & 16.48 & 19.74 & 0.83 & 2009 & 6.82 & 19.74 & 0.35 \\
\hline 2010 & 15.65 & 19.45 & 0.80 & 2010 & 7.90 & 19.95 & 0.40 \\
\hline 2011 & 12.33 & 19.48 & 0.63 & 2011 & 7.77 & 20.01 & 0.39 \\
\hline 2012 & 16.18 & 20.26 & 0.80 & 2012 & 7.70 & 20.07 & 0.38 \\
\hline 2013 & 15.59 & 20.67 & 0.75 & 2013 & 6.95 & 19.71 & 0.35 \\
\hline 2014 & 14.74 & 20.84 & 0.71 & 2014 & 8.78 & 19.56 & 0.45 \\
\hline 2015 & 15.08 & 19.91 & 0.76 & 2015 & 10.02 & 19.38 & 0.52 \\
\hline 2016 & 15.55 & 20.59 & 0.76 & 2016 & 9.15 & 20.10 & 0.46 \\
\hline 2017 & 15.39 & 19.94 & 0.77 & 2017 & 9.18 & 19.60 & 0.47 \\
\hline Ave. & 15.20 & 19.89 & 0.76 & Ave. & 5.32 & 20.15 & 0.27 \\
\hline \multicolumn{4}{|c|}{ MALI } & \multicolumn{4}{|c|}{ NIGER } \\
\hline Years & $\begin{array}{c}\text { Fiscal } \\
\text { Pressure }\end{array}$ & $\begin{array}{c}\text { Fiscal } \\
\text { Potential }\end{array}$ & Fiscal Effort & Years & $\begin{array}{c}\text { Fiscal } \\
\text { Pressure }\end{array}$ & $\begin{array}{c}\text { Fiscal } \\
\text { Potential }\end{array}$ & Fiscal Effort \\
\hline 1991 & 10.81 & 19.59 & 0.55 & 1991 & 7.02 & 19.33 & 0.36 \\
\hline 1992 & 9.84 & 19.56 & 0.50 & 1992 & 6.70 & 19.30 & 0.35 \\
\hline 1993 & 10.49 & 19.79 & 0.53 & 1993 & 6.57 & 19.64 & 0.33 \\
\hline 1994 & 8.88 & 20.51 & 0.43 & 1994 & 5.22 & 19.98 & 0.26 \\
\hline 1995 & 9.73 & 20.03 & 0.49 & 1995 & 6.55 & 19.89 & 0.33 \\
\hline 1996 & 12.15 & 20.01 & 0.61 & 1996 & 6.63 & 19.79 & 0.33 \\
\hline 1997 & 12.47 & 19.76 & 0.63 & 1997 & 7.21 & 19.85 & 0.36 \\
\hline
\end{tabular}




\section{Continued}

\begin{tabular}{|c|c|c|c|c|c|c|c|}
\hline 1998 & 12.94 & 20.30 & 0.64 & 1998 & 7.96 & 19.55 & 0.41 \\
\hline 1999 & 13.01 & 20.18 & 0.64 & 1999 & 8.10 & 19.96 & 0.41 \\
\hline 2000 & 12.34 & 19.49 & 0.63 & 2000 & 8.65 & 19.64 & 0.44 \\
\hline 2001 & 12.73 & 19.98 & 0.64 & 2001 & 9.28 & 19.85 & 0.47 \\
\hline 2002 & 13.77 & 19.92 & 0.69 & 2002 & 9.67 & 19.71 & 0.49 \\
\hline 2003 & 14.75 & 19.78 & 0.75 & 2003 & 9.91 & 19.83 & 0.50 \\
\hline 2004 & 14.82 & 19.85 & 0.75 & 2004 & 10.95 & 20.78 & 0.53 \\
\hline 2005 & 15.38 & 19.89 & 0.77 & 2005 & 10.20 & 19.45 & 0.52 \\
\hline 2006 & 14.95 & 19.72 & 0.76 & 2006 & 10.69 & 18.47 & 0.58 \\
\hline 2007 & 14.23 & 19.89 & 0.72 & 2007 & 11.36 & 19.89 & 0.57 \\
\hline 2008 & 13.27 & 19.42 & 0.68 & 2008 & 11.63 & 19.62 & 0.59 \\
\hline 2009 & 12.99 & 20.64 & 0.63 & 2009 & 13.46 & 19.36 & 0.70 \\
\hline 2010 & 12.89 & 19.44 & 0.66 & 2010 & 12.41 & 19.58 & 0.63 \\
\hline 2011 & 11.87 & 20.13 & 0.59 & 2011 & 21.13 & 20.07 & 1.05 \\
\hline 2012 & 11.94 & 19.21 & 0.62 & 2012 & 19.48 & 20.46 & 0.95 \\
\hline 2013 & 12.29 & 19.47 & 0.63 & 2013 & 19.40 & 19.90 & 0.97 \\
\hline 2014 & 12.52 & 20.00 & 0.63 & 2014 & 20.19 & 19.80 & 1.02 \\
\hline 2015 & 14.04 & 19.67 & 0.71 & 2015 & 23.09 & 19.83 & 1.16 \\
\hline 2016 & 14.90 & 19.81 & 0.75 & 2016 & 18.04 & 19.93 & 0.91 \\
\hline 2017 & 14.46 & 19.72 & 0.73 & 2017 & 18.90 & 19.63 & 0.96 \\
\hline Ave. & 12.76 & 19.84 & 0.64 & Ave. & 11.87 & 19.74 & 0.60 \\
\hline
\end{tabular}

\begin{tabular}{cccccccc}
\hline \multicolumn{4}{c}{ SENEGAL } & & \multicolumn{3}{c}{ TOGO } \\
\hline Years & $\begin{array}{c}\text { Fiscal } \\
\text { Pressure }\end{array}$ & $\begin{array}{c}\text { Fiscal } \\
\text { Potential }\end{array}$ & Fiscal Effort & Years & $\begin{array}{c}\text { Fiscal } \\
\text { Pressure }\end{array}$ & $\begin{array}{c}\text { Fiscal } \\
\text { Potential }\end{array}$ & Fiscal Effort \\
\hline 1991 & 15.72 & 19.77 & 0.79 & 1991 & 13.82 & 19.89 & 0.69 \\
1992 & 16.73 & 19.72 & 0.85 & 1992 & 11.19 & 19.89 & 0.56 \\
1993 & 14.47 & 19.59 & 0.74 & 1993 & 7.72 & 18.40 & 0.42 \\
1994 & 14.37 & 19.65 & 0.73 & 1994 & 9.92 & 21.37 & 0.46 \\
1995 & 15.39 & 19.98 & 0.77 & 1995 & 12.30 & 19.74 & 0.62 \\
1996 & 15.72 & 20.28 & 0.78 & 1996 & 12.13 & 19.40 & 0.63 \\
1997 & 15.98 & 19.70 & 0.81 & 1997 & 12.32 & 20.14 & 0.61 \\
1998 & 16.16 & 19.84 & 0.81 & 1998 & 12.80 & 20.34 & 0.63 \\
1999 & 16.98 & 19.79 & 0.86 & 1999 & 11.99 & 19.78 & 0.61 \\
2000 & 16.13 & 19.64 & 0.82 & $\mathbf{2 0 0 0}$ & 11.28 & 18.87 & 0.60 \\
2001 & 16.13 & 19.76 & 0.82 & $\mathbf{2 0 0 1}$ & 11.08 & 19.53 & 0.57 \\
2002 & 16.92 & 19.86 & 0.85 & $\mathbf{2 0 0 2}$ & 9.76 & 19.53 & 0.50 \\
2003 & 16.98 & 19.83 & 0.86 & $\mathbf{2 0 0 3}$ & 12.13 & 18.77 & 0.65 \\
\hline
\end{tabular}




\begin{tabular}{|c|c|c|c|c|c|c|c|}
\hline \multicolumn{8}{|c|}{ Continued } \\
\hline 2004 & 17.41 & 19.82 & 0.88 & 2004 & 13.51 & 20.02 & 0.67 \\
\hline 2005 & 18.53 & 19.65 & 0.94 & 2005 & 13.47 & 19.51 & 0.69 \\
\hline 2006 & 18.84 & 19.95 & 0.94 & 2006 & 14.58 & 20.18 & 0.72 \\
\hline 2007 & 19.26 & 19.77 & 0.97 & 2007 & 15.37 & 19.86 & 0.77 \\
\hline 2008 & 18.14 & 19.50 & 0.93 & 2008 & 14.25 & 19.98 & 0.71 \\
\hline 2009 & 17.98 & 20.13 & 0.89 & 2009 & 14.42 & 20.26 & 0.71 \\
\hline 2010 & 14.38 & 19.79 & 0.73 & 2010 & 14.54 & 19.50 & 0.75 \\
\hline 2011 & 14.63 & 19.66 & 0.74 & 2011 & 15.97 & 20.09 & 0.79 \\
\hline 2012 & 14.33 & 19.44 & 0.74 & 2012 & 16.57 & 18.51 & 0.90 \\
\hline 2013 & 14.10 & 19.57 & 0.72 & 2013 & 18.87 & 19.04 & 0.99 \\
\hline 2014 & 15.11 & 19.79 & 0.76 & 2014 & 20.28 & 20.55 & 0.99 \\
\hline 2015 & 15.15 & 19.70 & 0.77 & 2015 & 20.93 & 19.88 & 1.05 \\
\hline 2016 & 17.21 & 19.94 & 0.86 & 2016 & 21.68 & 19.99 & 1.08 \\
\hline 2017 & 15.81 & 20.01 & 0.79 & 2017 & 22.29 & 20.10 & 1.11 \\
\hline Ave. & 16.24 & 19.78 & 0.82 & Ave. & 14.26 & 19.74 & 0.72 \\
\hline
\end{tabular}

